\title{
Hubungan antara Beberapa Faktor Prognostik Klinikopatologik Karsinoma Kolorektal di RSUD Dr.Achmad Mochtar Bukittinggi Tahun 2015-2017
}

\author{
Loli Devianti',Salmiah Agus ${ }^{2}$
}

\begin{abstract}
Abstrak
Data histopatologi dari seluruh senter patologi di Indonesia tahun 2013 karsinoma rektum pada laki-laki menempati urutan ke-5 (1580 kasus) dan karsinoma kolon menempati urutan ke-9 (1123 kasus). Terdapat beberapa faktor prognostik klinikopatologik karsinoma kolorektal diantaranya umur, jenis kelamin, tipe histopatologik dan derajat diferensiasi. Tujuan penelitian ini adalah menentukan hubungan antara beberapa faktor prognostik klinikopatologik karsinoma kolorektal. Parameter prognostik klinikopatologik yang dipilih adalah umur, jenis kelamin, tipe histopatologik dan derajat diferensiasi. Penelitian ini merupakan cross sectional comparative study menggunakan sampel 145 kasus karsinoma kolorektal. Dilakukan pengumpulan status kiriman, preparat HE dan re-evaluasi slaid. Penelitian ini menganalisis data primer berupa hasil reevaluasi slaid HE terhadap tipe histopatologik dan derajat diferensiasi. Data sekunder berupa umur dan jenis kelamin yang tercatat pada status. Data dianalisis dengan univariat dan multivariate dengan menggunakan Chi-square test. Terdapat hubungan yang signifikan antara umur dengan tipe histopatologik dengan nilai $p=0,034(<0,05)$. Tidak terdapat hubungan yang signifikan antara umur dan derajat diferensiasi dengan nilai $p=0,184(>0,05)$. Tidak terdapat hubungan yang signifikan antara jenis kelamin dengan tipe histopatologik dengan nilai $p=0,628(>0,05)$. Tidak terdapat hubungan yang signifikan antara jenis kelamin dengan tipe derajat diferensiasi dengan nilai $p=0,868(>0,05)$.
\end{abstract}

Kata kunci: karsinoma kolorektal, umur, jenis kelamin, tipe histopatologik, derajat diferensiasi

\begin{abstract}
In Indonesia (2013), it was the fifth most common in man (1580 cases) and it was the ninth in woman (1123 cases). There are clinicopathological prognostics of colorectal carcinoma such as; age, sex, histopathological type and differentiation grade. The objective of this study was to determine the correlation among clinicopathological prognostic of colorectal carcinoma. This cross-sectional comparative study used 145 cases of colorectal cancer. Patient's record and HE slides were collected to review. Primary data (histopathological type and differentiation grade) were analysed. Secondary data (age and sex) were recorded. Data were analysed with Chi-square test. There was significant correlation between age and histopathological type, test showed $p=0.034(<0.05)$. There was no significant correlation between age and differentiation grade, test showed $p$-value $p=0.184(>0.05)$. There was no significant correlation between sex and histopathological type, test showed $p$-value $p=0.628(>0.05)$. There was no significant correlation between sex and differentiation grade, test showed $p$-value $p=0.868(>0.05)$.
\end{abstract}

Keywords: colorectal cancer, age, sex, histopathological type, differentiation grade.

Affiliasi penulis: 1. Ka KSM Patologi Anatomi RSUD Dr. Achmad Mochtar Bukittinggi, Staf Pengajar LB PPDS Patologi Anatomi FK Unand (Fakultas Kedokteran Universitas Andalas), 2. KSM Patologi Anatomi RSUD Dr. Achmad Mochtar Bukittinggi, Guru Besar/ Staf Pengajar LB PPDS Patologi Anatomi FK Unand (Fakultas Kedokteran Universitas Andalas)
Korespondensi: Loli Devianti Email: Iolidevianti@yahoo.comTelp/HP :085263009624 


\section{PENDAHULUAN}

Karsinoma kolorektal merupakan kanker tersering keempat di dunia pada laki-laki (setelah paru, prostat dan lambung) dan ketiga tersering pada wanita (setelah payudara dan servik). Diperkirakan sekitar 9,4 $\%$ dari seluruh kasus kanker pada tahun 2008, dengan lebih dari 1 juta kasus baru didiagnosis setiap tahun. Pada tahun 2012 diperkirakan 103.170 kasus baru karsinoma kolon dan 40.290 kasus baru karsinoma rektum. ${ }^{1}$ Di Amerika Serikat (AS), karsinoma kolorektal kanker tersering ke-3 baik pada perempuan (setelah kanker payudara dan paru) ataupun laki-laki (setelah kanker prostat dan paru). Tahun 2015, diperkirakan 132.700 kasus baru kanker kolorektal di AS, dengan

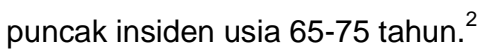

Data histopatologi dari seluruh senter patologi di Indonesia tahun 2013 karsinoma rektum pada lakilaki menempati urutan ke-5 dengan jumlah 1580 kasus dan karsinoma kolon menempati urutan ke-9 dengan jumlah 1123 kasus. Sedangkan pada wanita, karsinoma rektum di urutan ke-4 (1585 kasus) dan urutan ke-9 karsinoma kolon (1101 kasus).Di Sumatera Barat untuk laki-laki kanker kolon menempati urutan ke-3 (51 kasus) dan kanker rektum menempati urutan ke-4 (50 kasus). Sedangkan pada wanita kanker rektum di posisi ke-6 (51 kasus) dan kanker kolon di urutan ke-7 (43 kasus). ${ }^{3}$

Karsinoma kolorektal merupakan tumor ganas epitel kolon dan rektum. Ditandai dengan sel-sel tumor yang telah menginvasi muskularis mukosa sampai ke sub mukosa. ${ }^{1,4,5}$ Terdapat beberapa faktor prognostik klinikopatologik karsinoma kolorektal, diantaranya umur, jenis kelamin, tipe histopatologik dan derajat diferensiasi. ${ }^{5,6}$

Akibat meningkatnya usia harapan hidup pada populasi secara umum, terjadi peningkatan yang relatif pasien berumur lebih tua menderita karsinoma kolorektum. Jenis kelamin juga berpengaruh pada kekambuhan dan mortalitas, dimana pasien laki-laki memiliki prognosis yang lebih jelek dibandingkan perempuan. $^{5}$

Tipe histopatologi ikut menentukan faktor prediksi harapan hidup. ${ }^{1}$ Mayoritas tipe histopatologik karsinoma kolorektal adalah adenokarsinoma., ${ }^{2,-9}$ Tipe histopatologi adenokarsinoma musinosum, signet ring cellcarcinoma dan undiffrentiated carcinoma memiliki prognosis yang buruk. ${ }^{1,8}$

Derajat diferensiasi histopatologik merupakan faktor prognostik yang sangat penting didukung oleh penelitian dengan analisis statistik pada studi analisis multivariat. ${ }^{1}$ Derajat diferensiasi dinilai berdasarkan pembentukan struktur kelenjar. ${ }^{2}$ Direkomendasikan pembagian derajat diferensiasi menjadi dua, yaitu tumor derajat rendah (well dan moderate) dan tumor derajat tinggi (poorly). ${ }^{1,4}$

\section{METODE}

Penelitian ini menggunakan desain cross sectional comparative study, yaitu variabel independen dan dependen diperiksa pada saat yang bersamaan.

Populasi penelitian adalah semua slaid kasus karsinoma kolorektal yang didiagnosa di Laboratorium Patologi Anatomi (PA) RSUD dr. Achmad Mochtar Bukittinggi tahun 2015 sampai 2017. Sampel adalah bagian populasi yang sudah memenuhi kriteria inklusi dan eklusi. Jumlah sampel ditetapkan 145 kasus.

Penelitian dilakukan di Laboratorium PA RS dr. Achmad Mochtar Bukittinggi selama April sampai Mai 2018. Dilakukan pengumpulan data sekunder selama tahun 2015 sampai 2018, berupa status pasien, preparat HE yang telah didiagnosis dengan karsinoma kolorektal. Pemeriksaan ulang mikroskopik preparat (review) dilakukan di laboratorium Laboratorium PA RS dr. Achmad Mochtar Bukittinggi.

Data penelitian berupa kasus karsinoma kolorektal yang telah didiagnosis selama periode tahun 2015-1017 di Laboratorium PA RS dr. Achmad Mochtar Bukittinggi. Penelitian ini menganalisis data primer berupa hasil reevaluasi slaid HE terhadap tipe histopatologik dan derajat diferensiasi. Dilakukan pengumpulan slaid HE kemudian dilakukan reevaluasi tipe histopatologik dan derajat diferensiasi. Data sekunder berupa umur dan jenis kelamin yang tercatat pada status pemeriksaan pasien dikelompokkan dalam interval tertentu. Semua data dimasukkan ke dalam tabel distribusi frekuensi.

Data yang diperoleh diolah dan dianalisis dengan analisis univariat dan bivariat. Analisa univariat berupa deskripsi yaitu karakteristik umum (distribusi umur dan jenis kelamin), tipe histopatologik 
dan derajat diferensiasi yang disajikan dalam bentuk tabel distribusi frekuensi dan narasi.Analisis bivariat berupa uji statistik dengan menggunakan Chi-square test yang menganalisis data variabel independen skala ordinal dan variabel dependen skala nominal dan ordinal yaitu hubungan antara umur dan jenis kelamin dengan tipe histopatologik dan derajat diferensiasi karsinoma kolorektal. Hasil pengolahan data disajikan dalam bentuk tabel dan narasi. Keputusan hasil pengujian hipotesis dianggap bermakna secara statistik bilamana nilai $p<0,05$.

HASIL

Tabel 1. Gambaran karakteristik umum karsinoma kolorektal

\begin{tabular}{|c|c|c|}
\hline \multicolumn{2}{|c|}{ Karakteristik } & $\mathbf{N}(\%)$ \\
\hline \multicolumn{3}{|c|}{ Jenis Kelamin } \\
\hline - & Laki - laki & $72(49,7)$ \\
\hline- & Perempuan & $73(50,3)$ \\
\hline \multicolumn{3}{|c|}{ Umur Penderita } \\
\hline & Mean & 54,8 tahun \\
\hline & Range & $(\mathrm{SD} 13,768)$ \\
\hline \multicolumn{2}{|c|}{ Kelompok Umur } & $21-86$ \\
\hline \multicolumn{3}{|c|}{$\leq 30$} \\
\hline- & $31-40$ & $5(3,4)$ \\
\hline- & $41-50$ & $24(16,6)$ \\
\hline- & $51-60$ & $26(17,9)$ \\
\hline- & $61-70$ & $39(26,9)$ \\
\hline- & $>70$ & $34(23,4)$ \\
\hline \multicolumn{2}{|c|}{ Jenis Histopatologi } & $17(11,7)$ \\
\hline - & Adenokarsinoma musinosum & \\
\hline- & Adenokarsinoma usually type & $24(16,6)$ \\
\hline \multicolumn{2}{|c|}{ Derajat Diferensiasi } & $121(83,4)$ \\
\hline \multicolumn{3}{|c|}{ - Derajat rendah } \\
\hline \multirow{2}{*}{\multicolumn{2}{|c|}{ - $\quad$ Derajat tinggi }} & $116(80)$ \\
\hline & & $29(20)$ \\
\hline
\end{tabular}

Penelitian ini dilakukan pada 145 penderita kanker kolorektal, dimana jumlah penderita perempuan sedikit lebih banyak daripada laki - laki. Rata-rata umur penderita di atas 50 tahun dengan penderita terbanyak ditemukan pada kelompok umur 51 - 60 tahun. Semua kasus kanker kolorektal merupakan adenokarsinoma, dimana kelompok adenokarsinoma usually type merupakan jumlah terbanyak yaitu sebesar 121 kasus (83,4\%). Ditemukan kasus kanker kolorektal derajat rendah lebih banyak daripada derajat tinggi (Tabel 1).

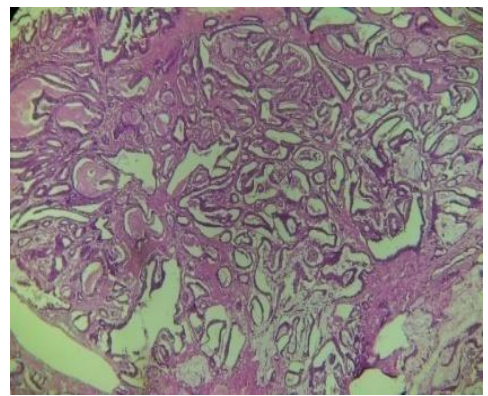

Gambar 1. Adenokarsinoma usually type, derajat rendah

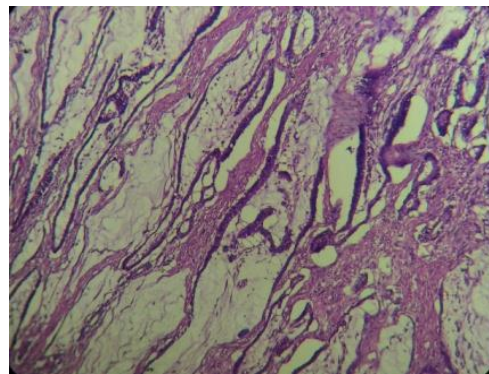

Gambar 2. Adenokarsinoma musinosum, derajat tingg

Tabel 2. Hubungan umur dengan tipe histopatologik karsinoma kolorekta

\begin{tabular}{|c|c|c|c|c|c|c|c|}
\hline \multirow{5}{*}{$\begin{array}{l}\text { Kelom- } \\
\text { pok } \\
\text { Umur }\end{array}$} & \multicolumn{4}{|c|}{ Tipe Histopatologik } & \multicolumn{2}{|c|}{ Total } & \multirow{5}{*}{$\mathbf{p}$} \\
\hline & \multirow{3}{*}{\multicolumn{2}{|c|}{$\begin{array}{c}\text { Adeno } \\
\text { karsinoma } \\
\text { Musinosum }\end{array}$}} & \multirow{3}{*}{\multicolumn{2}{|c|}{$\begin{array}{c}\text { Adeno } \\
\text { karsinoma } \\
\text { UsuallyType }\end{array}$}} & \multirow{4}{*}{ f } & \multirow{4}{*}{$\%$} & \\
\hline & & & & & & & \\
\hline & & & & & & & \\
\hline & $f$ & $\%$ & $\mathbf{f}$ & $\%$ & & & \\
\hline$\leq 55$ & 17 & 23,0 & 57 & 77,0 & 74 & 100 & \\
\hline tahun & & & & & & & 0,034 \\
\hline$>55$ & 7 & 9,9 & 64 & 90,1 & 71 & 100 & \\
\hline tahun & & & & & & & \\
\hline
\end{tabular}

Pada penelitian ini, sebanyak 57 kasus (77\%) penderita dengan kelompok umur $\leq 55$ tahun merupakan tipe histopatologik adenokarsinoma usually type. Pada penderita dengan kelompok umur >55 tahun, sebanyak 64 kasus $(90,1 \%)$ merupakan jenis adenokarsinoma usually type. Hasil uji statistik ditemukan hubungan yang signifikan antara umur dengan tipe histopatologik, nilai $p=0,034$ (Tabel 2). 
Tabel 3. Hubungan umur dengan derajat histopatologik karsinoma kolorektal.

\begin{tabular}{|c|c|c|c|c|c|c|c|}
\hline \multirow{4}{*}{$\begin{array}{l}\text { Kelom- } \\
\text { pok } \\
\text { Umur }\end{array}$} & \multicolumn{4}{|c|}{ Derajat Diferensiasi } & \multicolumn{2}{|c|}{ Total } & \multirow{4}{*}{$\mathbf{p}$} \\
\hline & \multirow{2}{*}{\multicolumn{2}{|c|}{$\begin{array}{l}\text { Derajat } \\
\text { Rendah }\end{array}$}} & \multirow{2}{*}{\multicolumn{2}{|c|}{$\begin{array}{c}\text { Derajat } \\
\text { Tinggi }\end{array}$}} & \multirow{3}{*}{$f$} & \multirow{3}{*}{$\%$} & \\
\hline & & & & & & & \\
\hline & $f$ & $\%$ & f & $\%$ & & & \\
\hline$\leq 55$ & 56 & 75,7 & 18 & 24,3 & 74 & 100 & \\
\hline tahun & & & & & & & 0,184 \\
\hline$>55$ & 60 & 84,5 & 11 & 15,5 & 71 & 100 & \\
\hline tahun & & & & & & & \\
\hline
\end{tabular}

Pada penelitian ini, sebanyak 56 kasus $(75,7 \%)$ penderita dengan kelompok umur $\leq 55$ tahun memiliki derajat diferensiasi rendah. Pada penderita dengan kelompok umur >55 tahun, sebanyak 60 kasus $(84,5 \%)$ juga memiliki derajat diferensiasi rendah. Hasil uji statistik tidak ditemukan hubungan yang signifikan antara umur dengan derajat diferensiasi, nilai $p=0,184$. (Tabel 3 )

Tabel 4. Hubungan jenis kelamin dengan tipe histopatologik karsinoma kolorektal

\begin{tabular}{|c|c|c|c|c|c|c|c|}
\hline Jenis & \multicolumn{4}{|c|}{ Tipe Histopatologik } & \multicolumn{2}{|c|}{ Total } & \multirow{5}{*}{$\mathbf{p}$} \\
\hline \multirow[t]{4}{*}{ Kelamin } & \multirow{3}{*}{\multicolumn{2}{|c|}{$\begin{array}{c}\text { Adeno } \\
\text { karsinoma } \\
\text { Musinosum }\end{array}$}} & \multirow{3}{*}{\multicolumn{2}{|c|}{$\begin{array}{c}\text { Adeno } \\
\text { karsinoma } \\
\text { UsuallyType }\end{array}$}} & \multirow{4}{*}{$\mathbf{f}$} & \multirow{4}{*}{$\%$} & \\
\hline & & & & & & & \\
\hline & & & & & & & \\
\hline & f & $\%$ & f & $\%$ & & & \\
\hline Laki - & 13 & 18,1 & 59 & 81,9 & 72 & 100 & \\
\hline laki & & & & & & & 0,628 \\
\hline Peremp & 11 & 15,1 & 62 & 84,9 & 73 & 100 & \\
\hline uan & & & & & & & \\
\hline
\end{tabular}

Pada penelitian ini, sebanyak 59 kasus (81,9\%) penderita dengan jenis kelamin laki-laki merupakan tipe histopatologik adenokarsinoma usually type. Pada penderita dengan jenis kelamin perempuan, sebanyak 62 kasus (84,9\%) juga merupakan tipe histopatologik adenokarsinoma usually type. Hasil uji statistik tidak ditemukan hubungan yang signifikan antara jenis kelamin dengan tipe histopatologik, nilai $p=0,628$ (Tabel 4).

Pada penelitian ini, sebanyak 58 kasus $(80,6 \%)$ penderita dengan jenis kelamin laki-laki memiliki derajat diferensiasi rendah. Pada penderita dengan jenis kelamin perempuan, sebanyak 58 kasus $(79,5 \%)$ juga memiliki derajat diferensiasi rendah. Hasil uji statistik tidak ditemukan hubungan yang signifikan antara jenis kelamin dengan derajat diferensiasi, nilai $p=0,868$. (Tabel 5)

Tabel 5. Hubungan jenis kelamin dengan derajat diferensiasi karsinoma kolorektal

\begin{tabular}{lrrrrrrr}
\hline Jenis & \multicolumn{2}{c}{ Derajat Diferensiasi } & \multicolumn{3}{c}{ Total } \\
Kelamin & $\begin{array}{c}\text { Derajat } \\
\text { Rendah }\end{array}$ & \multicolumn{2}{c}{$\begin{array}{c}\text { Derajat } \\
\text { Tinggi }\end{array}$} & f & $\%$ & p \\
& f & $\%$ & $\mathbf{f}$ & $\%$ & & & \\
& 58 & 80,6 & 14 & 19,4 & 72 & 100 & \\
\hline Laki- & 58 & & & & & & 0,868 \\
laki & & & & & & & \\
Perem- & 58 & 79,5 & 15 & 20,5 & 73 & 100 & \\
puan & & & & & & & \\
\hline
\end{tabular}

\section{PEMBAHASAN}

Ada beberapa faktor prognostik klinikopatologik untuk karsinoma kolorektal. Beberapa diantaranya adalah umur, jenis kelamin, tipe histopatologik dan derajat diferensiasi. ${ }^{1,2,5,9}$

Pada penelitian jumlah penderita perempuan sedikit lebih banyak daripada laki-laki. Hal ini sedikit berbeda dengan mayoritas literatur yang menerangkan bahwa karsinoma kolorektal lebih sering terjadi pada jenis kelamin laki-laki. ${ }^{1,2,4}$ Novitasari dan Mulyadi (2016) melakukan penelitian terhadap 227 kasus karsinoma kolorektal di RSUP Sanglah, juga menemukan paling banyak pada jenis kelamin lakilaki(55,9\%). ${ }^{10}$ Beberapa penelitian lain yang dilakukan Gotra dan Moestikaningsih di RSUP Sanglah, Hajmanoochehri et al di Iran, Park et al di Korea dan Chong et al di Brunai Darussalam juga menemukan karsinoma kolorektal lebih banyak pada laki-laki. ${ }^{11-14}$ Perbedaan ini mungkin dipengaruhi oleh faktor resiko lainnya seperti faktor lingkungan. Peningkatan resiko pada laki-laki diperkirakan berkaitan dengan status hormonal dan dikaitkan dengan rokok. ${ }^{1}$ Sedangkan pada penelitian yang lain oleh Jayadi et al (2013) yang melakukan penelitian di RSUP Sardjito Yogyakarta mendapatkan hasil dimana jumlah perempuan lebih banyak dari laki-laki. ${ }^{15}$

Rata-rata umur penderita pada penelitian ini adalah di atas 50 tahun dengan penderita terbanyak ditemukan pada kelompok umur 51 - 60 tahun. Umur termuda adalah 21 tahun dan umur tertua adalah 86 tahun. Hal ini sesuai dengan literatur bahwa karsinoma kolorektal sering muncul pada usia 
pertengahan dan lebih tua. ${ }^{1,2}$ Pada penelitian lain juga didapatkan hasil rerata umur 50 tahun. ${ }^{10,16}$ Kemungkinan besar terkait dengan faktor lingkungan dan gaya hidup. Semakin panjang usia seseorang, semakin lama terpapar dengan lingkungan. Faktor lingkungan diantaranya diet daging merah, obesitas, merokok, alkohol, penggunaan kontrasepsi oral, estrogen eksogen dan kurang olah raga. ${ }^{1,2}$

Semua kasus kanker kolorektal pada penelitian ini merupakan adenokarsinoma, dimana kelompok adenokarsinoma usually type merupakan jumlah terbanyak yaitu sebesar 121 kasus (83,4\%). Hasil ini sesuai dengan litertur bahwa adenokarsinoma usually type merupakan tipe histopatologik tersering dari karsinoma kolorektal. ${ }^{1,2,4,8}$ Pada penelitian lain Novitasari dan Mulyadi juga mendapatkan adenokarsinoma sebagai kasus terbanyak sebesar $84,1 \% .{ }^{10}$ Chong et al dalam penelitiannya menemukan jenis adenokarsinoma juga paling banyak yaitu $97,57 \%{ }^{14}$

Dalam penelitian ini ditemukan kasus kanker kolorektal derajat rendah lebih banyak daripada derajat tinggi masing-masing $80 \%$ dan $20 \%$. Hasil ini sesuai dengan penelitian yang dilakukan Novitasari dan Mulyadi, Gotra dan Moestikaningsih, Jayadi et al, dimana derajat diferensiasi rendah ditemukan lebih banyak. $^{10,11,15}$

Telah dilakukan analisis hubungan antara faktor-faktor prognostik klinikopatologik di atas dengan uji statistik. Yaitu hubungan umur dengan tipe histopatologik karsinoma kolorektal, hubungan umur dengan derajat diferensiasi karsinoma kolorektal, hubungan jenis kelamin dengan tipe histopatologik karsinoma kolorektal dan hubungan jenis kelamin dengan derajat diferensiasi karsinoma kolorektal.

Pada penelitian ini didapatkan hubungan yang signifikan antara umur dengan tipe histopatologik, nilai $p=0,034$. Sebanyak 57 kasus (77\%) penderita dengan kelompok umur $\leq 55$ tahun merupakan tipe histopatologik adenokarsinoma usually type. Pada penderita dengan kelompok umur >55 tahun, sebanyak 64 kasus $(90,1 \%)$ merupakan jenis adenokarsinoma usually type. Hajmanoochehri et al yang melakukan penelitian gambaran klinikopatologik terhadap 232 kasus adenokarsinoma kolon, menemukan hubungan hubungan yang signifikan antara umur dan tipe histopatologik $(p=0,001) .{ }^{12} \mathrm{Hal}$ ini berbeda dengan penelitian yang dilakukan oleh Novitasari dan Mulyadi yang meneliti antar parameter klinikopatologis pada karsinoma kolorektal post reseksi dengan menganalisa 227 kasus, dimana tidak terdapat hubungan yang signifikan antara umur dan tipe histopatologik. ${ }^{10}$ Park et al dalam penelitiannya membandingkan prognostik antara adenokarsinoma musinosum dengan non musinosum pada 6475 pasien stadium 1 sampai 3, mendapatkan hasil bahwa pasien adenokarsinomamusinosum lebih banyak ditemukan pada usia muda. ${ }^{13}$

Sebanyak 56 kasus (75,7\%) penderita dengan kelompok umur $\leq 55$ tahun memiliki derajat diferensiasi rendah dalam penelitian ini. Pada penderita dengan kelompok umur >55 tahun, sebanyak 60 kasus (84,5\%) juga memiliki derajat diferensiasi rendah. Hasil uji statistik tidak ditemukan hubungan yang signifikan antara umur dengan derajat diferensiasi, nilai $p=0,184$. Hal ini sama dengan penelitian yang dilakukan Hajmanoochehri et al, serta Novitasari dan Mulyadi, dimana tidak terdapat hubungan yang signifikan antara umur dengan derajat diferensiasi. $^{10,12}$

Pada penelitian ini sebanyak 59 kasus (81,9\%) penderita dengan jenis kelamin laki-laki merupakan tipe histopatologik adenokarsinoma usually type. Pada penderita dengan jenis kelamin perempuan, sebanyak 62 kasus (84,9\%) juga merupakan tipe histopatologik adenokarsinoma usually type. Hasil uji statistik tidak ditemukan hubungan yang signifikan antara jenis kelamin dengan tipe histopatologik, nilai $p=0,628$. Hal ini sama dengan penelitian Hajmanoochehri et al, serta Novitasari dan Mulyadi, dimana tidak terdapat hubungan yang signifikan antara jenis kelamin dengan tipe histopatologik. ${ }^{10,12}$

Penelitian ini menemukan sebanyak 58 kasus $(80,6 \%)$ penderita dengan jenis kelamin laki-laki memiliki derajat diferensiasi rendah. Pada penderita dengan jenis kelamin perempuan, sebanyak 58 kasus $(79,5 \%)$ juga memiliki derajat diferensiasi rendah. Hasil uji statistik tidak ditemukan hubungan yang signifikan antara jenis kelamin dengan derajat diferensiasi, nilai $p=0,868$. Hal ini sama dengan penelitian Novitasari dan Muyadi dimana tidak 
terdapat hubungan yang signifikan antara jenis kelamin dengan derajat diferensiasi. ${ }^{10}$

\section{SIMPULAN}

Terdapat hubungan yang signifikan secara statistik antara umur dengan tipe histopatologik. Tidak terdapat hubungan yang signifikan antara umur dan derajat diferensiasi, jenis kelamin dengan tipe histopatologik dan jenis kelamin dengan tipe derajat diferensiasi.

\section{DAFTAR PUSTAKA}

1. Redston M. Epithelial neoplasmsof the large intestine. Dalam: Odze R, Goldblum J, editor (penyunting). Surgical pathology of the Gl tract, liver, biliary tract and pancreas. Edisi ke-3. Philadelphia: Elsevier; 2015.hlm.737-62.

2. Pai RK, Gonzalo DH, Schaffer DF. Epithelial neoplasms of the colon. Dalam: Fenoglio-Preiser's Gastrointestinal Pathology. Edisi ke-4. Philadelphia: Wolters Kluwe; 2017.hIm.855-27.

3. Badan Registrasi Kanker Perhimpunan Dokter Spesialis Patologi Indonesia. Kanker di Indonesia tahun 2013, data histopatologik. Jakarta: Yayasan Kanker Indonesia; 2017.

4. International Academy of Pathology (IAP). Carcinoma of the colon and rectum. Dalam: WHO classification of tumours of pathology and genetics of tumours of the digestive system. Lyon; 2000. hlm.105-11.

5. Dziki A. Prognostic factors in rectal cancer. Klinicka Onkologie;1999.hlm.33-5.

6. Sjo $\mathrm{OH}$. Prognostic factors in colon cancer [tesis]. Oslo: Universityof Oslo; 2012.
7. Divitiis CD, Nasti G, Montano M, Fisichella R, laffaioli RV, Berretta M. Prognostic and Predictive Response Factors in Colorectal Cancer Patients: Between Hope and Reality. World J Gastroenterol. 2014;20(41):15049-59.

8. Rosai J. Rosai and Ackerman's surgical pathology. Edisi ke-10. Philadelphia: Elsevier; 2011.hlm.76171.

9. Fletcher C. Diagnostic histopathology of the tumours. Edisi ke-4. Philadelphia: Elsevier; 2013. hlm.457-61.

10. Novitasari, Mulyadi IK. Hubungan antar parameter klinikopatologis pada karsinoma kolorektal postreseksi: analisis 227 kasus periode tahun 20102014. Medicina. 2016;4(1):30-8.

11. Gotra IM, Moestikaningsih. Perbedaan ekspresi Cox-2 pada beberapa parameter klinikopatologi adenokarsinoma kolorektal. Majalah Patologi Indonesia. 2012;21(2):17-22.

12. Hajmanoochehri F, Asefzadeh S, Kazemifar AH, Ebtehaj M. Clinicopathological features of colon adenocarcinoma in Qazvin, Iran: a 16 year study. Asian Pac J Cancer Prev. 2014;15(2):951-5.

13. Park JS, Huh JW, Park YA, Cho YB, Yun SH, Kim $\mathrm{HC}$, etal. Prognostic comparison between mucinous and nonmucinous adenocarcinoma in colorectal cancer. Medicine. 2015;94(15):e658.

14. Chong VH, Abdullah MS, Telisinghe PU, Jalihal A. Colorectal cancer: Incidence and trend in Brunai Darussalam.Singapore Med J.2009;50(11):1085-9.

15. Jayadi T, Harijadi, Tirtoprodjo P. Hubungan ekspresi protein NM23-H1, densitas limfovaskuler peri-tumoral dan invasi limfovaskuler dengan stadium dan diferensiasi histopatologi adenokarsinoma kolorektal. Majalah Patologi Indonesia. 2013;22(2):1-6. 